\title{
The Difference In Diversity: Dynamics Of Interaction Of Foreign Workers With Local Communities In Serang-Cilegon, Indonesia
}

\author{
Anis Fuad ${ }^{1}$, Ika Arinia Indriyany ${ }^{2}$, Mahpudin ${ }^{3}$ \\ Departement of Governance Science, University of Sultan Ageng Tirtayasa ${ }^{123}$ \\ \{anis.fuad@untirta.ac.id\}
}

\begin{abstract}
This study wants to see the presence of foreign workers in the Serang-Cilegon. So far, existing studies view the relationship between them as a conflictual relationship using a structuralist or security approach. This article offers a multiculturalism approach in understanding the interaction between them. By using the political recognition strategy, we hoped that the potential conflicts could be minimized. Then we can design a conflict prevention model. Qualitative research with a case study approach was chosen as the research method. Data was collected through a literature study of several relevant references. The findings show that their interaction can trigger tensions that lead to conflict, especially regarding economic and socio-cultural issues. This effect happens because of the weak state control in regulating foreign workers and managing differences. The prevention model offered is a multiculturalism approach, which creates a politics of recognition in the community through a willingness to accept diversity.
\end{abstract}

Keywords: Conflict Prevention, Diversity, Foreign Workers, Multiculturalism

\section{Introduction}

Banten Province is an area that has industrial areas spread from Tangerang City to Lebak Regency. The latest data from BPS shows that currently, large and medium industrial companies in Banten Province are 2,515 companies, while micro and small industries are 113,139 companies [1]. The company employs 647,398 workers who are divided into local workers and foreign workers [1]. One of the areas with the highest concentration of foreign workers in Banten Province is Serang Regency and Cilegon City.

Cilegon City is an industrial area in Banten, especially for the steel industry. Apart from PT. Krakatau Steel which has been established for a long time, is one of the steel factories, which is a global collaboration between PT. Krakatau Steel and POSCO Korea are PT. Krakatau Posco. The company was founded in 2010 with the philosophy of Partnership for Sustainable Growth. The consequence of this cooperation is the large number of foreign workers who enter Cilegon, especially South Korean citizens. Data from the Manpower and Transmigration Office of Banten Province shows that in 2021, the number of foreign workers in Cilegon City will be 459 people, and South Korean citizens will reach 51\%, followed by the People's Republic of China with $18 \%$. At PT Krakatau Posco itself, there are 65 foreign workers.

In Serang Regency, one of the major industrial centers in Banten Province, also has more or less the same problem. According to data from the Manpower and Transmigration Office of Banten Province, in 2021, there will be 505 foreign workers. With the largest concentration of foreign workers in PT NIKOMAS GEMILANG. PT NIKOMAS GEMILANG is a company 
engaged in producing various types of shoes with the trademarks of Nike, Adidas, and Puma, with $100 \%$ production products exported outside Indonesia. For countries of origin, foreign workers in Serang Regency are dominated by Chinese workers at 53\%, then Taiwan workers with $19 \%$.

The development of investment and industrialization in Cilegon City and Serang Regency is not directly proportional to local employment conditions. With the presence of industrialization, ideally, it is expected to improve the welfare of the people in a region. In 2020, Cilegon will be an area with an unemployment rate of $12.69 \%$. This number increased significantly in the last three years, $9.68 \%$ in 2019 and $9.33 \%$ in 2018 [2]. Meanwhile, unemployment in Serang Regency shows a more low number, which is the second-highest in Banten Province under Tangerang Regency [1]. These phenomena show that industrial development does not have a significant impact on the absorption of local workers.

This phenomenon triggers gaps that can lead to conflict. Various problems arise due to the presence of foreign workers such as the rise of foreign restaurants such as Korean, Japanese, so on. which provide non-halal food, the emergence of prostitution places wrapped in Korean restaurants in Cilegon City, the prohibition of worship for Muslim workers by foreign employers, as well as several incidents of violence.

This study aims to photograph the dynamics of the interaction between foreign workers and local communities. So far, existing studies tend to view the relationship between foreign workers and the local community as a conflictual relationship. The approach used is always a structuralist and security approach. This study tries to offer a different approach, namely the multiculturalism approach to understand the interactions that occur. By using the strategy of political recognition, it is hoped that the potential for tensions that trigger conflicts between foreign workers and local communities can be minimized. This study seeks to provide an indepth analysis of the patterns and forms of interactions that occur and then design the most relevant conflict prevention model to overcome existing problems by prioritizing cultural understanding, both for local communities and foreign workers.

\section{Conceptual Framework}

The multiculturalism approach is often used as an approach in looking at the differences that exist in society [3] [4]. Multiculturalism is a paradigm of efforts to re-knit conflicting human relationships [5] [6]. The strategy used to encourage Multiculturalism is the Politics of Recognition. Politics of Recognition provides an opportunity to recognize minority groups or groups not benefited, which are then outlined in the rule of law policy [7]. This Recognition Politics can be used as a basis for creating togetherness between groups to create an inclusive and humanist society [8].

In managing potential conflicts, local governments must play an active role [9][10]. First, maintaining good relations between the three institutions: entrepreneurs, the community, and the government itself. Local governments can play a mediating role in the event of a conflict between entrepreneurs and the community. Triggers of conflict between employers and the community can occur when the company's activities interfere and deviate from what is expected by the community. The dilemma will arise when the local government is in a dilemmatic position between defending the interests of the community or maintaining the company's existence [9].

Second, local governments must have control over both the minimum wage and control over the use of labor by foreign companies. This control is carried out to reduce the potential for conflict between foreign and local workers. Therefore, a clear and systematic division of 
labor is needed by the company. The excessive use of labor from outside the region by the company often leads to community dissatisfaction and impacts conflict between the company and the community [9]. Third, local governments must ensure that all authority in foreign investment matters is not in the central government. This effort includes the authority for licensing and supervising foreign investment.

Studies on the presence of foreign workers have been carried out in several countries. In Singapore, it is explained that foreign labor conflicts arise because foreign workers position themselves negatively compared to the local community's ideology, culture, and language [11]. Ideology, culture, and language are the most significant sources of discrimination for foreign workers in Singapore. When these foreign workers can remove the existing language barrier, the discrimination for them also disappears. Therefore, this research offers a discourse strategy as one of the ways that can be adopted to minimize the potential for conflict.

The challenge of managing foreign workers is not only experienced by Singapore. Malaysia is also experiencing this. The challenge facing Malaysia is that the government does not have enough capacity to issue foreign workers policies and conduct studies related to the need for workers both from within the country and abroad [12]. Malaysia is one of the favorite countries visited by foreign workers who aim to improve their economic status. The irony that happened in Malaysia is that foreign workers have become the favorite choice. This phenomenon happened because they tend to be easier to control, willing to be given any work contract, and willing to be given a low salary with a long working time [12].

The study conducted by Ajis also found that foreign workers who are not appropriately managed by the state can pose a national threat because this involves aspects of the military, macroeconomic, social culture, politics, migration, and energy sources. One way that can be done is to ensure that the policies issued regarding migration and foreign workers are based on serious research. In addition, the state must have full power and control over foreign workers. So far, many companies control foreign workers.

\section{Methods}

The method used in this study is a qualitative descriptive method with a case study approach. Qualitative research does not seek or explain relationships, tests hypotheses, or makes predictions but makes systematic, factual, and accurate descriptions [13]. Through qualitative research, researchers can identify subjects and feel what they experience in everyday life. According to this definition, qualitative research produces descriptive data from a phenomenon under study [14]. This study aims to provide an overview of a particular social phenomenon and answer questions with a more detailed explanation of the social phenomena in the research problem.

While the approach used is a case study approach. A case study is a research design where the research process is carried out in-depth and comprehensively on the case selected by the researcher [13]. Therefore, the selected case is also specific, detailed, unique, and exciting [15]. In this study, the case selected was foreign workers in Serang Regency and Cilegon City.

Data collection in this study was carried out through literature studies. Literature studies are related to documents related to foreign workers in Banten Province originating from journals, research documents, government reports, and other documents.

This data is then triangulated to ensure the validity of the data obtained. Power triangulation is re-checking the correctness of the data and its interpretation:

a. Source Triangulation compares and re-checks the degree of trust in information obtained through different times and tools. 
b. Methods Triangulation can be applied by checking the degree of confidence in the research findings on several power collection techniques or checking the degree of confidence in several data sources with the same method.

c. Triangulation with investigators utilizes other researchers or observers to re-check the degree of trustworthiness of the data.

d. Triangulation with theory, namely re-checking the truth of the phenomenon by using a different theory.

\section{Social Setting Serang-Cilegon}

Initially, Serang-Cilegon was the same administrative area under the government of Serang Regency, West Java Province. However, since decentralization began to be implemented in the reform era, there has been a massive regional expansion. Through Law number 5 of 1999 , Cilegon officially separated from Serang Regency to become an autonomous city. The separation of Cilegon from Serang Regency is one of the efforts to accelerate forming a separate Banten Province from West Java. This effort found its climax in 2000, Banten became a new province. Cilegon and Serang are two of the eight regencies/cities that are included in the administrative area of the Banten Province government.

Geographically, Serang-Cilegon is included as a strategic area. Cilegon, for example, became the meeting point of the Trans Sumatra and Java routes, so that it also determined the development and growth of the two islands. There is a large port, namely the Merak port, which is accessible for the mobility of goods and people to become one of the critical economic pillars for Cilegon. In addition, Cilegon also has a transportation route that connects to Jakarta (the nation's capital city) via the Jakarta-Merak toll road. This condition makes Cilegon a strategic area as the location of the world economy.

Meanwhile, Serang Regency is geographically located in the middle of the Banten Province. This location provides a distinct advantage because it facilitates the mobility of goods and people and supports the surrounding area. Serang Regency is also a transit gate connecting the islands of Java and Sumatra. In the west, Serang Regency is bordered by Cilegon City and bordered by Tangerang Regency in the east. While in the south, it is bordered by Lebak Regency, and in the north, it is bordered by Serang City and the Java Sea.

As a strategic area, Serang-Cilegon is used as one of the pillars of the growth center in Banten Province. This phenomenon is reinforced by government documents contained in the Spatial Planning and Regional Planning of Banten Province that the three regions consisting of Serang Regency, Serang City, and Cilegon City function as a development stimulus for supporting areas that are oriented towards economic centers in various regions, namely industry, ports, marine, tourism, mining, and services. In addition, because of its adjacent location, several socio-economic activities have a condition that requires the two regions to synergize.

For example, immigration matters for expatriates in Bojonegara are under the supervision of the Cilegon City Immigration Office, even though Bojonegara itself is a subdistrict that belongs to the Serang Regency government because the location of Bojonegara is closer to Cilegon than the administrative center of Serang Regency. Another example, Kramatwatu, Serang Regency, is one of the domicile points for foreigners working in Cilegon.

Although Cilegon and Serang are two different areas, these two areas have similar socioeconomic characteristics, namely as one of the supporting areas for industrial activities. Cilegon, for example, is known as a steel industrial area through PT Krakatau Steel, the largest steel 
factory in Indonesia. Likewise with PT Nikomas Gemilang is one of the well-known icons attached to Serang Regency. This company is the largest shoe manufacturer in Southeast Asia. These two well-known companies absorb thousands of workers. In 2018, there were 6,269 employees of PT Krakatau Steel [16]. While in 2017, there were 56,000 workers at PT Nikomas Gemilang [17]. These two well-known companies and various other companies also thrive in Serang-Cilegon to become the central pillar of the economy.

Referring to data obtained from the Manpower Office of Cilegon City in 2020, it is known that as many as 1923 companies are still operating. Meanwhile, BPS data shows that in 2018 there were 236 large and medium industries in Serang Regency [1]. The fact that SerangCilegon is an industrial area has complex implications. On the one hand, it has positive implications because it can stimulate the community's economy's movement, including increasing income for local government budgets. However, on the other hand, negative implications are also unavoidable. The company's activities will impact the surrounding natural and human environment, as well as on values, culture, and local wisdom [18].

Although these two areas are classified as industrial areas, they are not directly proportional to the absorption of local workers. This statement is confirmed by the fact that the ratio of job chances is not directly proportional to the ratio of job seekers. In Cilegon City, for example, in 2016, the number of job seekers was 10,011 people with a workforce application rate of only 711 people [19]. The impact is increasing the unemployment rate. The number of unemployed in Cilegon City continues to increase every year. In 2020, based on data released by BPS, Cilegon City has the second-largest unemployment rate in Banten Province [20]. The same thing happened in Serang Regency. In 2012, Serang Regency had the highest unemployment rate in Banten Province, although it has shown a significant decline. This condition raises a paradox because it turns out that regions that have significant to mediumscale industries still have serious problems related to unemployment. In other words, the absorption of local labor from indigenous peoples has not been significant. This factor can become a potential conflict in the future if not this issue is not managed correctly.

In the socio-cultural aspect, the people of Serang-Cilegon are very thick with Islamic nuances. This aspect can not be separated from the historical fact that this area once stood for the Islamic kingdom of Banten, which was quite large before the Dutch colonials tore it down in 1813. The kingdom of Banten has succeeded in passing down Islamic culture and values to the next generation to this day. The nuances of Islam have become an inherent part of the norms and order of daily life for the people of Serang-Cilegon. Many famous Kiai and Ulama were born from this area. For example, Kiai Syam'un (1894-1949) was an influential cleric in Banten and the Al Khairiyah Islamic boarding school in Cilegon. In 2018, President Jokowi awarded Kiai Syam'un the title of a national hero. In Serang Regency, a famous cleric, Sheikh Nawawi (1813-1897), wrote various Islamic books and had many santri followers spread across various regions. On this basis, Serang-Cilegon has nicknamed a million students and made the majority of the population Muslim.

The existing condition that the community has Islamic local culture and wisdom can be a potential conflict when faced with things that can clash with the values believed by the local community. The people of Cilegon City adhere to the principle that there should be no other house of worship besides the mosque. The implication is that no other houses of worship have been found in Cilegon [21]. Meanwhile, in Serang Regency, entrepreneurs or the government who want to build factories often encounter resistance from the local community-driven by Kiai and santri [22]. Including the fact that Serang-Cilegon is an industrial area that absorbs workers from other regions and foreign workers so that it can trigger social tensions due to clashes of values and culture. 
The description of the Serang-Cilegon setting in this section confirms that the existing condition of these two areas as one of the industrial areas in Banten Province has the potential for conflict. The presence of the industry, in fact, still leaves the problem of absorption of local labor, which leads to the creation of unemployment. In addition, local communities have unique local wisdom to potentially trigger conflict if there is a clash of values and culture. In other words, the potential conflicts that arise have a complex and multi-factor character based on economic, social, and cultural problems. This problem includes potential conflicts between local communities and foreign workers as part of the arena and actors in the conflict itself.

\section{Development of Foreign Workers in Serang-Cilegon}

The flow of globalization and modernization marked by the penetration of technology and industrialization has forced countries to be open and accommodate changes in various fields. On the one hand, industrialization is an influential agenda for the government to trigger development. Because industrialization is considered the driving force of a country's economy and is expected to be directly proportional to the welfare of its citizens [23] [24], on the other hand, to fulfill the industrialization project, it is necessary to be supported by high-quality human resources. The problem is that the quality of human resources in developing countries, including Indonesia, is still low, so it is necessary to hire foreign workers to carry out company activities that are considered unable to be managed by local communities. Moreover, Indonesia has joined a global system based on a free market, one of which is the ease of regulation on the mobility of foreigners to enter and leave various countries. The implication is that the presence of foreign workers is a necessity.

Regulations regarding foreign workers are contained in Law number 11 of 2020 concerning Job Creation and strengthened by Government Regulation number 34 of 2021 concerning the Use of Foreign Workers. The regulation defines foreign workers as "foreign citizens holding visas to work in Indonesian territory." The essence of this regulation outlines that foreign workers are needed to accelerate and improve the investment and business climate with specific and limited provisions and conditions. Foreign workers who may enter Indonesia only fill positions and within a certain period. In article 3 , it is stated that the provider of foreign workers can come from: Government agencies, foreign private companies in Indonesia, social institutions, and other agencies or business entities as long as they comply with regulations. Legal foreign workers is those who have the RPTKA (Plan for the Use of Foreign Workers) and IMTKA (Permit to Use Foreign Workers) from the Ministry of Manpower.

The presence of foreign workers in Cilegon and Serang is closely related to companies in the area, both government-owned and private-owned companies. Based on official data obtained from the Banten Province Manpower and Transmigration Service in 2021, the number of foreign workers in Cilegon City is 459 people spread across various companies in Cilegon. Meanwhile, foreign workers who work for companies in the Serang Regency area are 505 people. A detailed description can be seen in the following table:

Table 1. Number of Foreign Workers in Serang Cilegon by Company

\begin{tabular}{|l|c|l|c|}
\hline \multicolumn{1}{|c|}{ Company in Serang } & Number & \multicolumn{1}{c|}{ Company in Cilegon } & Number \\
\hline PT Nikomas Gemilang & 63 & PT Krakatau Steel & 78 \\
\hline PT Polyplex Films Indonesia & 30 & PT Krakatau Posco & 65 \\
\hline PT Indahkiat Pulp \& Paper Tbk & 28 & PT Posco Ict Indonesia & 41 \\
\hline PT Pou Chen Indonesia & 26 & PT Growth Java Industry & 35 \\
\hline
\end{tabular}




\begin{tabular}{|c|c|c|c|}
\hline PT Gunung Mulia Steel & 21 & PT KPMS Indonesia & 34 \\
\hline PT Shun Fa Langgeng Jaya Steel & 21 & PT MC Pet Film Indonesia & 27 \\
\hline PT Gemilang Pratama Karya & 16 & PT Nippon Shokubai & 23 \\
\hline PT Vita Prodana Mandiri & 15 & PT Semen Jakarta & 18 \\
\hline PT Hwa Hok Steel & 14 & PT Indonesia Pos Chemtech & 9 \\
\hline PT Shiva Sakti Steel & 13 & PT Krakatau Posco C.C & 8 \\
\hline PT Haohan Cement & 12 & PT Nippon Steel Texeng & 7 \\
\hline PT Flextech Packaging Indonesia & 11 & PT Krakatau Posco Energy & 6 \\
\hline PT Xiang Wang Indonesia & 11 & PT KRNG Indonesia & 6 \\
\hline PT San Fang Indonesia & 10 & PT MCA Indonesia & 6 \\
\hline Another Company & 214 & Another Company & 96 \\
\hline Total & 505 & Total & 495 \\
\hline
\end{tabular}

Source: Banten Province Manpower and Transmigration Service in 2021

The table above illustrates that the number of foreign workers in Serang Regency working at PT Nikomas Gemilang is 63 people, then PT Polyplex Films Indonesia has 30 foreign workers. Meanwhile, other foreign workers are spread to other companies, which, when accumulated, the number reaches 214 foreign workers. Meanwhile, foreign workers in Cilegon City mostly worked at PT Krakatau Steel as many as 78 people, then PT Krakatau Posco as many as 65 people and spread to other companies reaching 96 people.

Table 2. Distribution of Foreign Workers in Serang Cilegon Country of Origin

\begin{tabular}{|c|c|c|c|}
\hline $\begin{array}{c}\text { Origin Country of Foreign } \\
\text { Workers Serang }\end{array}$ & Number & $\begin{array}{c}\text { Origin Country of Foreign } \\
\text { Workers Cilegon }\end{array}$ & Jumlah \\
\hline People's Republic of China & 266 & Republic of Korea & 235 \\
\hline Republic of China, Taiwan & 95 & People's Republic of China & 82 \\
\hline Republic of Korea & 44 & Japan & 69 \\
\hline Republic of India & 35 & Federal Republic of Germany & 38 \\
\hline Federal Republic of Germany & 13 & Republic of India & 8 \\
\hline Italy & 12 & Italy & 5 \\
\hline Japan & 12 & Philippines & 4 \\
\hline Malaysia & 10 & Malaysia & 3 \\
\hline Another country & 18 & Another country & 15 \\
\hline $\begin{array}{r}\text { Total } \\
\end{array}$ & 505 & Total & 495 \\
\hline
\end{tabular}

Source: Banten Province Manpower and Transmigration Service in 2021

The table above explains that the most foreign workers working in companies in Serang Regency are from China, with as many as 266 people. Furthermore, as many as 95 foreign workers from Taiwan and 44 foreign workers from South Korea. In contrast, the number of foreign workers in Cilegon City who came from South Korea is 235 people, China's s82 people, and Japan's 69 people.

Apart from government documents dealing with the number of legal foreign workers, many illegal foreign workers are still working for Cilegon and Serang companies. The 2016 case strengthens this argument that the Banten Police have secured as many as 70 Chinese foreign workers suspected of being illegal. They work at PT Conch, which is located in the Pulo Ampel area, Serang Regency. After going through the examination process at the Immigration Office, 35 foreign workers were illegal and had to be deported because they did not have official work permits [25]. Meanwhile, in 2019, the local government of Cilegon City found 51 illegal 
foreign workers from South Korea who worked at PT Krakatau Posco Maintenance Service [26]. These findings confirm that the presence of foreign workers could be more than the official data held by the government.

The countries of origin of foreign workers vary, although they are predominantly from Asian countries. Foreign workers working for Cilegon and Serang are dominated by South Korea, China, and Japan because most entrepreneurs are from that country. For example, PT Krakatau Posco in Cilegon is a joint venture between the Indonesian government's PT Krakatau Steel and PT Pohang Iron and Steel Company (Posco). Posco owns 70\% of the shares; the remaining $30 \%$ belongs to Indonesia. Posco is a foreign-owned company from South Korea, so many foreign workers who work for this company are from South Korea. The same thing happened to PT Conch Cement Indonesia in Puloampel, Serang Regency. The company operates in extractive industries such as coal, nickel, cement, and wood exports. The company, founded in 2011, is the result of bilateral relations between China and Indonesia. Therefore, most of the foreign workers who work for the company are from China.

The domicile of foreign workers is spread across various regions and even across regions from the company. For example, not all foreign workers who work for companies in Cilegon are domiciled in the exact location but other places. The same thing applies to foreign workers in Serang Regency. Few foreign workers work in Cilegon but live in Serang Regency, especially in the Serang-Cilegon border areas such as in Kramatwatu and Pulo Ampel. This condition causes difficulties in the supervision process carried out by the relevant government officials [27]. Due to the cross-regional distribution of foreign workers, Serang-Cilegon becomes a unified analysis in this paper to see the relationship between foreign workers and local communities in socio-economic life.

\section{The Relationship between Foreign Workers and Local Residents: Friction and Potential Conflict}

The relationship between foreign workers and residents raises an analytical question that whether the pattern of relations created between different elements of the community produces a harmonious, integral, and tolerant relationship by respecting and respecting differences, or whether the relationship that is built triggers the formation of negative sentiments fulfilled mutual suspicion that leads to a conflictual relationship. How is the government and stakeholders' approach in managing the lives of these different people? These questions can be identified with the detailed description in this section.

The relationship between foreign workers and residents does not show a dominant interaction. This phenomenon happened because the number of foreign workers in an area is far less than the total population of the local population. As an illustration, in 2021, the number of foreign workers in Cilegon will be 459 people, while the number of residents will reach more than 434,896 people. It means that the percentage of foreign workers in Cilegon is only $0.11 \%$. In Serang Regency, foreign workers are 507 people, and the local population is 1.6 million people.

Thus, the percentage of foreign workers in Serang Regency is only $0.031 \%$. Looking at this data, it seems that the presence of foreign workers does not have a significant impact on the lives of local people. However, empirical findings show that the presence of foreign workers still influences the lives of local communities, even though on a smaller scale. These results certainly cannot go unnoticed because if this reality exists, it will become a latent danger that 
will cause more significant turmoil in society. Some of the potential conflicts that occur between foreign workers and local communities are as follows.

First, the potential conflict comes from economic motives. The economy is one of the fundamental needs of individuals. The company's existence is expected to contribute to improving the economic level of the surrounding community, for example, seen from the absorption of local workers. However, the presence of foreign workers is considered to be disturbing the local economy because job opportunities are limited. Normatively, foreign workers are imported to Indonesia to fill particular skills companies need because local workers do not have the required skills. Therefore, foreign workers work only in strategic positions, not as unskilled laborers. As long as local workers can still carry out the position or position in the company, the use of foreign workers is prohibited.

However, the perception that emerged in the community was that foreign workers had narrowed the available job opportunities. Because of this, their presence is often considered only to bring harm. The implication is that residents have negative sentiments in responding to the presence of foreign workers. For example, in the 2019 case in Serang, residents argued with representatives from foreign workers after seeing a group of foreign workers from China walking into a residential area. The Head of Immigration Serang conducted an inspection and confirmed that the foreign workers from China lived in Serang and worked in Cilegon, namely PT Krakatau Engineering. The attitude of the local community objected to the arrival of foreign workers who were domiciled in one of the housing estates in Serang [28].

This case did not turn into an open conflict because the relevant officials immediately took action and ensured that the Chinese foreign workers in question were legal and not unskilled. However, the community's initial acceptance of foreign workers was not good, evidenced by the debate between residents and foreign workers. Residents are concerned that the presence of foreign workers can disrupt the lives of residents, especially since foreign workers live side-by-side with residents' housing.

The suspicion of residents against foreign workers is very reasonable because in several cases in the Serang-Cilegon area, illegal foreign workers are often found and have the status of unskilled workers. In 2016, for example, the Cilegon City Manpower and Transmigration Service, together with representatives of several community leaders, supervised PT Heng Tai Yuan Indonesia Steel Group. This monitoring was carried out after Disnaker received many reports from residents that the company employed many Chinese foreign workers suspected of being illegal. The examination results confirmed residents' reports that 13 foreign workers from China did not have official documents. In addition, it is also known that these foreign workers from China cannot speak English and Indonesian, thus confirming that they work as manual laborers because they do not have particular skills required by the company as per government regulations [29].

Still, in the same year, the Banten Police found as many as 70 illegal Chinese foreign workers working at the PT Conch Cement Indonesia company, Puloampel, Serang Regency. They were declared illegal because the official documents for their work permits had expired. In addition, some of these foreign workers from China admitted that they only elementary school and junior high school graduates, so they only work as manual laborers. Even though they are unskilled laborers, they get paid 15 million per month from the company contrast to local workers who are only paid 2 million even though they are both manual laborers [30]. This phenomenon then disturbed the surrounding community so that it further strengthened the negative sentiment and image of foreign workers that their presence had robbed residents of working rights. 
In addition, residents feel excluded and experience discriminatory treatment because the wages for labor are minimal compared to the wages received by foreign workers. The problem of foreign workers is legal or illegal and has implications for the pattern of relations created between foreign workers and residents. The negative image attached to foreign workers often triggers rejection from residents. In some areas, demonstrations took place as a form of protest against the presence of foreign workers under government regulations. For example, in 2018, the United Kareo Village Community Forum (FMKB) held a demonstration in front of PT Kenda located in Serang. The masses demanded that the company not use foreign workers because, at the same time, the absorption of local workers at the company was deficient. The existence of PT Kenda is not directly proportional to the opening of job opportunities for residents. It sparked anger and frustration among residents [31].

Not only the company side but government officials are also often the target of residents anger and frustration with the existence of foreign workers. The Class II Immigration Office of Cilegon City was once visited by a group of members of the Red and White Defender Command Unit (KKPMP). They held demonstrations in response to many illegal foreign workers and foreign workers who worked as unskilled laborers. Meanwhile, unemployment is still an acute problem for residents in Cilegon. They also complained about the role of relevant government agency officials in supervising foreign workers and not prioritizing local workers. This mass group then assumed that local officials favored foreign workers, which was reinforced by the allegation that Cilegon government officials tended to be secretive in providing public information regarding the presence of foreign workers [32].

From these cases, it can be seen that the relationship between foreign workers and local workers tends to be conflictual even though it does not lead to open conflict, which leads to acts of violence and anarchy. The interactions that occur generate negative sentiments towards foreign workers. Economic factors drive this. The reality is different, contrasting by residents in responding to the presence of foreign workers. On the one hand, many companies employ foreign workers, but some of the existing foreign workers are illegal, without official permission from the government. Because it is illegal, foreign workers work as manual labor, but the company pays very high salaries. On the other hand, many residents feel that they are not benefited by the existence of companies that exist in their area. In addition, local workers get low wages.

Second, socio-cultural factors. Foreign workers are not only understood to be limited to economic affairs, namely foreigners working in Indonesia. More broadly than that, foreign workers have a set of values, norms, and cultures used as the basis for how they live. In this context, the potential for conflict is difficult to avoid because foreign workers and local communities rely on different cultural values and norms. Foreign workers tend to have a free lifestyle. In addition, the impact of the presence of foreign workers is the number of stalls selling liquor, entertainment venues, and restaurants that provide non-halal food menus. It is available to meet the needs of foreign workers. Even the sellers are from residents. This situation contrasts with the culture of the local community, which is very thick with Islamic values. As a Muslimmajority population base, there is a principle that entertainment venues, liquor, and non-halal food are prohibited in Islam. There is some concern that the presence of foreign workers will bring bad morals to residents.

The implication is that there is a clash of values and culture between foreign workers and residents. At Pondok Cilegon Indah (PCI), the borderline connecting Cilegon and Serang were once raided by residents for selling liquor. Likewise, the South Ring Road (JLS) area is a location for the proliferation of entertainment venues that foreign workers often visit. The local community often demonstrates plenty of entertainment at JLS because their existence is 
considered disturbing [34]. In some cases, conflicts between local communities occurred because they defended their superiors, who were none other than foreign workers. That is, it is precisely the foreign workers who cause friction between communities [19].

The interaction between foreign workers and local communities does not run intensively. When at the company, foreign workers and workers local workers do not have spaces for interaction. Their existence in the company is limited to work relations. Even among them have their respective job desks that are work-oriented so that it does not allow for personal and social communication and interaction. Likewise, outside of company affairs, the domicile of foreign workers is divided into two categories. Foreign workers living around the company's area and foreign workers living outside the company's area are scattered in various areas side by side with residents' settlements. Foreign workers domiciled outside the company's area occupy hotels, housing complexes specially provided for foreign workers, and rented houses owned by residents.

Foreign workers who live in the same area will make it easier for the supervisory function to work for the local government. However, the exclusive localization of foreign workers' residences has closed the opportunity for inclusive interactions with residents. Meanwhile, foreign workers who live side by side with residents' housing, on the one hand, allow for intensive communication so that it is expected to create a constructive relationship between them. Nevertheless, empirical reality shows that although foreign workers live side by side with residents, they live their own lives without any social coherence.

In a social order with various identities but no channels that allow these different groups to interact with each other, it tends to generate negative sentiments and hatred. It is because they do not know each other. This condition can be dangerous if other factors provoke disputes. For example, economic problems such as local people becoming unemployed and less prosperous tend to be associated with the presence of foreign workers. Finally, there is a biased perception that foreign workers are a source of problems for local communities. As has happened in many cases in Serang-Cilegon, people feel restless and insecure when they find out that foreign workers are in their area.

Feelings of restlessness, insecurity, and loss of local community trust, both to foreign workers who are considered the source of the problem and to the government as the party that manages foreign affairs are sources of conflict. Bartos reveal that conflict occurs when actors exhibit certain behaviors, such as antagonism, resistance, and opposition [33]. Actions of demonstrations, bullying, and negative sentiments are expressions of the conflict itself. The local community cannot control the worries, failures, and frustrations they face, so conflict becomes a channel for expressing emotions.

In other words, the portrait of the interaction between foreign workers and residents is closed and exclusive. There are no spaces for intensive communication to get to know, understand, and acknowledge each other's group identity. It has implications for creating negative sentiment towards foreign workers and the potential for conflict between them. However, this potential conflict is not open conflict. This argument simultaneously strengthens Furnivall's thesis on plural society [34] that plural society is characterized by the presence of two or more different elements of society. They live side by side but do not blend into a political unit, which triggers friction because there is no will to live together.

In this context, the existing condition of the Serang-Cilegon community can be categorized as a plural society, in which there are foreign workers and residents who live side by side but do not form a unity so that it has the potential for conflict. There is a clear demarcation line between them, giving rise to the dichotomy of foreign workers and local 
communities. Each considers a different community so that they live life in groups and individually.

\section{Multiculturalism: An Approach to Overcoming Potential Conflict}

The government has made various efforts in managing relations between foreign workers and local communities to prevent and minimize potential conflicts so that a harmonious life can be achieved. However, the approach used so far tends to prioritize security, structural, and formal legal aspects as research produced by Wahyudi [19] that the government's role in managing potential conflicts is to form a Foreigner Monitoring Team. This team combines cross-government agencies, namely Manpower, Immigration, Ministry of Law and Human Rights, Police, and the Body of National and Political Unity. This team not only functions in supervising foreign workers but also foreigners in general. This supervision is carried out to ensure that foreigners are legally legal and maintain social conduciveness in their location. The implemented programs include holding several outreach forums to the public to be aware of foreign workers and providing sanctions to foreign workers or companies that are proven to have violated them.

However, prevention efforts like this illustrate a less than ideal approach because it places foreign workers as marginal subjects and even objects of supervision by the apparatus. It means that there is an unequal relationship between foreign workers and the local community. It can be seen, for example, from a government program that aims to provide socialization and understanding to the local community so that they are always aware of foreign workers because they are considered to be able to disrupt stability and have a negative impact [19]. Steps like this reinforce the bad sentiment towards foreign workers in the local community's imagination that foreign workers are a source of problems. Moreover, the government carried out the socialization so that it seemed to have justified the existing sentiments. The implication is that efforts to prevent potential conflicts are not intact because, from the start, the local community has been indoctrinated constantly to be vigilant. Alertness is a signal in response to possible danger or enemy.

Therefore, we try to offer another alternative approach using a multiculturalism perspective. Multiculturalism is an approach that prioritizes common interests even though it relies on different communities [3]. Multiculturalism is reflected in the presence of politics of recognition, namely the recognition of minority communities who are not benefited and interactions between groups take place respecting differences, without discrimination and neglect of human rights.

Due to the pluralistic character of society, which tends to generate friction, Furnivall [34] emphasizes the need for conditions that allow these different societies to blend into a unified political unit. Based on this argument, the government needs to create a space and arena that allows foreign workers and local communities to meet, communicate, and understand each of the unique characteristics inherent among them. This meeting room and the arena are designed by prioritizing the principles of equality, justice, and tolerance in which foreign workers recognize and respect the existence of local communities and vice versa. This meeting space and arena can be encouraged within the company environment in terms of work relations and the community environment in the context of socio-cultural relations. Spaces and arenas are certainly not only created but need to be filled by substantial activities.

Concrete steps that the government can take, for example, are holding activities that include understanding the local community regarding the introduction of the status of foreign 
workers, the rights and obligations attached to foreign workers, and the culture and lifestyle of foreign workers. Likewise, foreign workers need to understand the character of the local community along with their values, norms, and culture. For example, they hold a people's competition which is participated by foreign workers and local communities. Meanwhile, in the company, for example, it is necessary to have activities that allow the involvement of the two communities. The multiculturalism approach emphasizes the role of civil society. Nevertheless, the government needs to be present as an actor who bridges the two parties, foreign workers and local communities. Therefore, the government needs to present policies based on a multicultural approach.

\section{Conclusion}

The interaction pattern between foreign workers and local communities in the SerangCilegon area can trigger tensions that lead to conflictual relations, especially regarding economic and socio-cultural issues. In the economic aspect, there is a perception that the presence of foreign workers has brought problems to local communities, such as narrowing employment opportunities. The number of illegal foreign workers working as unskilled laborers and a very high wage gap has contributed to a negative image and sentiment towards foreign workers. Meanwhile, in the socio-cultural aspect, there are differences in values and identities that collide. Foreign workers with free lifestyles and patterns are not compatible with local community culture, which is very thick with Islamic culture.

Meanwhile, in everyday life, the portrait of the interaction between foreign workers and the community is very closed and exclusive. No space or arena allows them to know and appreciate each other. The implication is that this kind of condition has led to the emergence of anxiety, concern, and distrust of the local community towards the existence of foreign workers. It tends to cause conflict. Demonstrations, demolitions, and negative sentiments against foreign workers are part of the expression of the conflict. In other words, the potential for conflict exists even though it cannot be said to be an open conflict. This article offers a multicultural approach as an alternative in managing differences and minimizing potential conflicts, namely creating a politics of recognition in the community through a willingness to accept diversity. This project needs to be supported by various stakeholders, especially the government, by presenting policies with a multicultural perspective.

\section{Acknowlegment}

We want to thank all those who contributed to the completion of this manuscript very well. Our special thanks go to the Ministry of Research and Technology for funding this research.

\section{References}

[1] BPS Provinsi Banten, Provinsi Banten Dalam Angka 2021. Banten: CV Dharmaputra, 2021.

[2] BPS Kota Cilegon, "Kota Cilegon dalam Angka 2021," Cilegon, 2021.

[3] P. Pederson, Multicultural Conflict Resolution. In: The Handbook of conflict Resolution: Theory and Practice. Wiley Publishing, 2006.

[4] A. Sarah, "Conflict Resolution in The Value of Multicultural Society Tradition: A Case Study of Buginese Community in East Kalimantan," University of Gadjah Mada, 2015. 
[5] S. Suardi and U. M. Makassar, "Masyarakat multikulturalisme indonesia," no. December, 2017, doi: 10.13140/RG.2.2.29013.32484.

[6] J. Mukherjee, Conflict Resolution in Multicultural Society: The Indian Experience. India: SAGE Publications Asia-Pacific Pte Ltd, 2014.

[7] S. Suharno, "Kebijakan Peraturan Daerah Berbasis Politik Rekognisi dan Resolusi Konflik Etnik."

[8] T. Svetelj, "Politics of Recognition: The Guideline for Modern Humanism," Int. J. Civ., vol. 10, no. 4, 2013, doi: 10.18848/2327-0047/CGP/v10i04/58259 Authors:

[9] A. Afadlal, Modal Asing dan Otonomi Daerah Banten. Jakarta: LIPI Press.

[10] F. Chowdhury, "Cultural Diversity in Mediation and Conflict Resolution," 2014. .

[11] Rubdy, Rani, and S. L. Mvc Kay, "Foreign Workers' in Singapore: Conflicting Discourses, Language Politics and The Negotiation of Immigrant Identities," Int. J. Soc. Lang., 2013, doi: DOI 10.1515/ijsl-2013-0036.

[12] Ajis and M. Naaeim, "The Dilemma of Managing Foreign Workers in Malaysia: Opportunities and Challenges," Polit. Sci., vol. 14, no. 4, 2014.

[13] J. W. Creswell and J. D. Creswell, Qualitative, Quantitative, and Mixed Methods Approaches, Fifth. United State of America: SAGE Publications, 2018.

[14] M. B. Miles, A. M. Huberman, and J. Saldana, Qualitative Data Analysis. California: SAGE Publications, 2014.

[15] R. K. Yin, Case Study Research, Design and Methods. California: SAGE Publications, 2003.

[16] Liputan6.com, "Cerita Bos Krakatau Steel Setahun Lobi Restrukrurisasi Utang Rp 2 Miliar Ke Sana Sini," 2017. .

[17] Radarbanten.co.id, "3.000 Buruh Nikomas Terancam di PHK,” 2018. .

[18] S. . Waluyo, B. Wahyudi, and A. Dohamid, Tenaga Kerja Asing di Cilegon dalam Perspektif Ketahanan Negara. Bogor, 2017.

[19] B. Wahyudi, S. . Waluyo, and N. Susilawati, Pencegahan Konflik Tenaga Kerja Indonesia dan Tenaga Kerja Asing Di Kota Cilegon Provinsi Banten. Bogor, 2017.

[20] Faktabanten.co.id, "Daerah Urutan Kedua Se-Banten Angka Pengangguran Kota Cilegon Naik jadi 1269," 2020. https://faktabanten.co.id/daerah/2urutan-kedua-se-banten-angka-pengangguran-kotacilegon-naik-jadi-1269/.

[21] R. Riswanda, M. D. Hikmawan, G. Ramadhan, and B. Nurrohman, "Making sense of the politics of recognition: Indicators of religious tolerance in Banten, Indonesia," Int. J. Eng. Res. Technol, vol. 13, no. 11, pp. 3386-3397, 2020, doi: 10.37624/ijert/13.11.2020.3386-3397.

[22] M. D. Hikmawan, I. Indriyany, and Y. Mayrudin, "Environmental Movement Against Mining Exploration in Bojonegara Serang Banten," in Advances in Social Science, Education and Humanities Research, 2019, vol. 367, no. ICDeSA, pp. 278-282, doi: 10.2991/icdesa-19.2019.57.

[23] S. . Lipset, Political Man: The Social Bases of Politics. United States: Doubleday \& Company, 1960.

[24] W. . Rostow, The Stages of Economic Growth. Cambridge: Cambridge Universiti Press, 1960.

[25] Mediaindonesia.com, "Polda Banten Amankan 70 TKA Ilegal Asal China," 2016. https://mediaindonesia.com/nusantara/59480/polda-banten-amankan-70-tka-ilegal-asal-china.

[26] Faktabanten.co.id, "Ditemukan 51 Tenaga Kerja Asing Diduga Ilegal di PT KMPS Cilegon," 2016. https://faktabanten.co.id/industri/ditemukan-51-tenaga-kerja-asing-diduga-ilegal-di-pt-kpmscilegon/.

[27] Biem, "Disnaker Kabupaten Serang Kesulitan Pantau Tenaga Kerja Asing," 2015. https://www.biem.co/read/2015/09/11/430/disnaker-kabupaten-serang-kesulitan-pantau-tenagakerja-asing/.

[28] detikcom, "Viral Video Tka di Cilegon Dihadang, Begini Faktanya," 2019. https://news.detik.com/berita/d-4458424/viral-video-tka-di-cilegon-dihadang-begini-faktanya.

[29] Titiknol, "Sidak Disnaker Cilegon Temukan Pekerja Tiongkok yang Diduga Ilegal," 2016. https://titiknol.co.id/peristiwa/sidak-disnaker-cilegon-temukan-pekerja-tiongkok-yang-didugailegal/.

[30] Vivaco.id, "Buruh Cina Digaji 15 Juta, Pekerja Lokal 2 Juta Sebulan," 2016. https://www.viva.co.id/berita/nasional/803909-buruh-china-digaji-15-juta--pekerja-lokal-2-jutasebulan. 
[31] Rmolbanten, "Ajak Masyarakat untuk Promosikan Wisata dan Produk Lokal," 2018. https://www.rmolbanten.com/read/2018/06/24/1572/1/Lisda-Hendrajoni-Ajak-Masyarakat-untukPromosikan-Wisata-dan-Produk-Lokal-Pessel.?page $=1$.

[32] Rmolbanten, "Imigrasi Cilegon Dituding Main Mata dalam Pengawasan TKA," 2016. https://titiknol.co.id/peristiwa/imigrasi-cilegon-dituding-main-mata-dalam-pengawasan-tka/.

[33] B. J. Otomar and P. Wehr, Using Conflict Theory. Cambridge: Cambridge University Press, 2002.

[34] J. . Furnivall, Furnivall's Plural Society and Leach's Political Systems of Highland Burma Reviewed Work, Colonial Policy and Practice : A Comparative Study of Burma and Netherlands India. 2019. 